International Journal of Civil Engineering Research.

ISSN 2278-3652 Volume 8, Number 2 (2017), pp. 69-79

(C) Research India Publications

https://dx.doi.org/10.37622/IJCER/8.2.2017.69-79

\title{
Seismic Analysis of Open Ground Storey Building
}

\author{
Akshay S. Paidalwar ${ }^{1}$ and G.D. Awchat ${ }^{2}$ \\ ${ }^{1}$ M-Tech Structural Engineering, Department of Civil Engineering, Guru Nanak \\ Institute of Technology, Nagpur, India. \\ ${ }^{2}$ Associate Professor, Department of Civil Engineering, Guru Nanak Institute of \\ Technology, Nagpur, India.
}

\begin{abstract}
Soft storey is one of the main reasons for building damage during an earthquake and has been mentioned in all investigation report. Soft storey due to increase storey height is well known subject. Change in amount infill walls between stories also results in soft story. These are usually not considered as a part of load bearing system. This study investigates the soft storey behavior due to lack of infills at ground floor storey and existence of this case by means of linear static and nonlinear static analysis for midrise reinforced concrete building. Soft storey behavior due to change in infill's amount is evaluated in view of the displacement, drift demand and structural behaviour.
\end{abstract}

Keywords - Soft storey; linear analysis; Seismic zones; Equivalent diagonal strut.

\section{INTRODUCTION}

Stability of earth is always disturbed due to internal forces and as a result of such disturbance, vibration or jerks in earth crust takes place which is known as earthquake. The fundamental design concept of earthquake resistance design of building is to make strong column and weak beam but many building that collapse during past earthquake exhibited exactly opposite strong beam and weak column behavior, means column failed before the beam yielding mainly due to soft storey effect. 
A Weak storey is defined as one in which the storey lateral strength is less than $80 \%$ of that storey above. The storey lateral strength is that total strength of all seismic resisting elements sharing the storey shear for the direction under consideration i.e. the shear capacity of column or the shear wall or horizontal component of the axial capacity of the diagonal braced. The deficiency that usually makes a storey weak is due to inadequate strength of frame column. The essential characteristics of weak or soft storey consist of a discontinuity of strength or stiffness which occurs in second storey connection. This discontinuity results lesser strength or increase flexibility, the structure result in extreme deflection in the first storey of the structure. The result is a concentration of electrification.

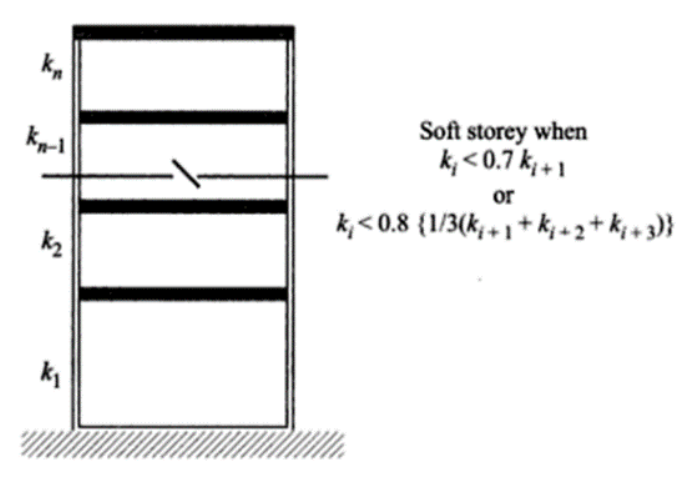

Fig.1 Stiffness irregularities- Soft storey

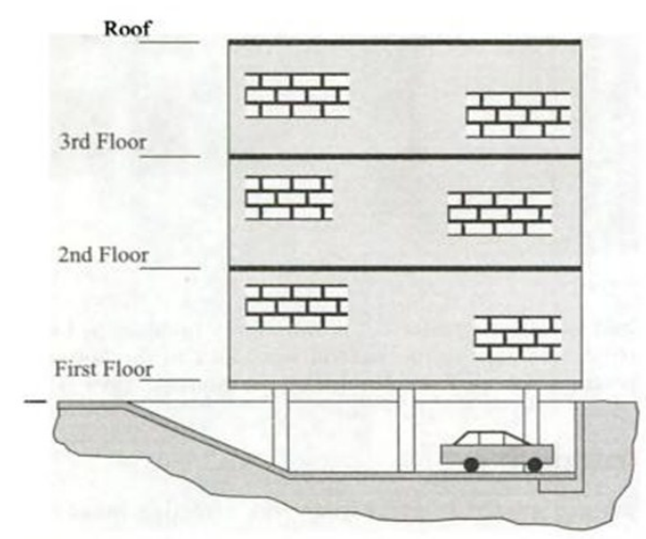

Fig. 2 Soft storey type construction

\section{SOFT STOREY}

The building in which the ground storey consist of open space for parking area is known as stilt building and the parking storey is called as stilt floor or soft storey. When sudden change of stiffness takes place along the building. The soft storey is most common 
features of the soft storey irregularity. It is usually present in modern frame building when large number of nonstructural rigid components, such as masonry infill attached to the column of upper floor of reinforced concrete frame structure, while the first storey is left empty of walls or with a reduced number of walls in comparison to the upper floor. The rigid nonstructural component limits the ability to deform of the column, modifying the structural performance of the building to the horizontal force. In a regular building, the earthquake shear force increase towards the first storey.

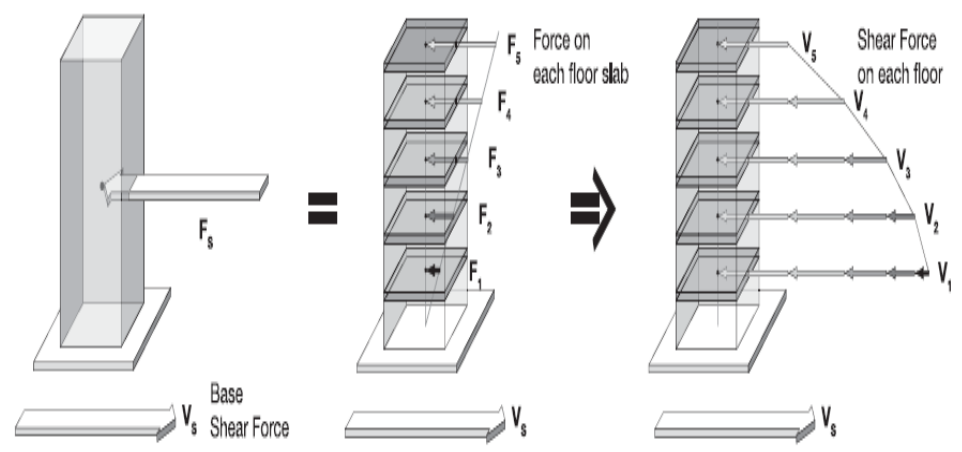

Fig.3 Lateral forces and Shear forces generated in buildings due to ground motion

The total displacement induced by an earthquake tends to distribute homogeneously in each floor through the height of the building. Deformation in each floor would be similar. When a more flexible portion of lower part of the building supports a rigid and more massive portion, the bulk energy will be absorbed by the lower significantly more flexible storey while small remainder of energy will be distributing amongst the upper storey, producing on the most flexible floor, large relative displacement between the lower and upper slab of the soft storey (inter storey drift) and therefore, the column of this floor will be subjected to large deformation.

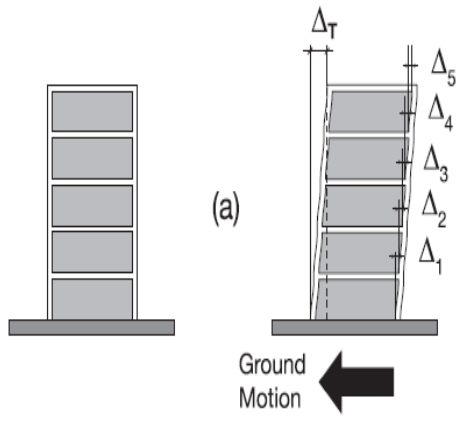

a) Regular building

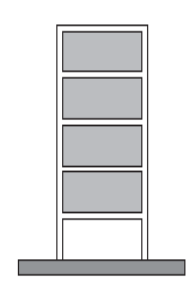

(b)

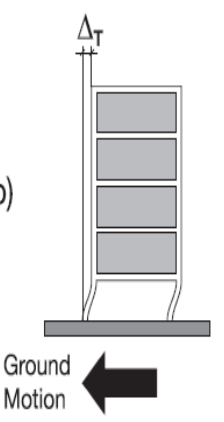

b) Building with soft story

Fig. 4 Distribution of total displacement generated by an earthquake 


\section{EQUIVALENT DIAGONAL STRUT METHOD}

In this method the infill is modeled as equivalent diagonal strut, having same thickness as infill but its effective width may depend upon number of factors. Table 1 shows empirical expressions available for width of strut on the basis of studies conducted by various investigators.

Table 1. Empirical expressions available for width of strut

\begin{tabular}{|l|l|}
\hline Investigator & Formula \\
\hline Stafford smith and Hendry (1963) & $w=1 / 2 \sqrt{\left(\alpha_{h}^{2}+\alpha_{L}^{2}\right)}$ \\
\hline Holmes (1963) & $w=d / 3$ \\
\hline Smith and Carter (1969) & $w=0.58\left(\frac{l}{h}\right)^{-0.445}(\lambda H)^{0.335 d\left(\frac{l}{h}\right)^{0.064}}$ \\
\hline Mainstone, R.J. (1971) & $w=0.175\left(\lambda_{h} H\right)^{-0.4} d$ \\
\hline Bazan and Meli, R (1982) & $w=(0.35+0.22 \beta) h$ \\
\hline Liauw and Kwan (1984) & \\
\hline Paulay, T and Priestly (1991) & $w=0.25 d$ \\
\hline Angle, R (1994) & $w=d / 8$ \\
\hline
\end{tabular}

Where, $\mathrm{W}=$ effective width of strut

$\beta=(\mathrm{Ec} \mathrm{Ac}) /(\mathrm{Gm} \mathrm{Am})$ is a dimensionless parameter

$\lambda=$ contact length parameter

$\mathrm{Ei}=$ Modulus of elasticity of infill material

$\mathrm{Ef}=$ Modulus of elasticity of frame material

$\mathrm{Ic}=$ Moment of inertia of column

$\mathrm{t}=$ thickness of infill Fig 2.1 shows the variable $\mathrm{h}, \mathrm{d}$ and $\mathrm{\theta}$

A. Stafford smith and Hendry

$$
\begin{aligned}
& \mathrm{W}=\frac{1}{2} \times \sqrt{\alpha h^{2}+\alpha l^{2}} \\
& \mathrm{E}_{\mathrm{f}}=25000 \mathrm{~N} / \mathrm{m} 2 \\
& \mathrm{Em}=25000 \mathrm{~N} / \mathrm{m} 2 \\
& \mathrm{t}=150 \mathrm{~mm}
\end{aligned}
$$




$$
\begin{aligned}
& \mathrm{Ic}=\frac{b d^{3}}{12}=\frac{0.6 \times 0.6^{3}}{12}=0.0108 \mathrm{~m}^{4} \\
& \mathrm{Ib}=\frac{b d^{3}}{12}=\frac{0.2 \times 0.6^{3}}{12}=0.0036 \mathrm{~m}^{4} \\
& \alpha h=\frac{\pi}{2}\left[\frac{E f \times I c \times h}{2 \times E m \times t \times \sin 2 \theta}\right]^{\frac{1}{4}} \\
& \alpha h=\frac{\pi}{2}\left[\frac{25000 \times 0.0108 \times 3.6}{2 \times 25000 \times 0.150 \times \sin 2 \times 31}\right]^{\frac{1}{4}} \\
& \alpha h=0.69 \mathrm{~m} \\
& \alpha l=\pi\left[\frac{E f \times I b \times l}{E m \times t \times \sin 2 \theta}\right]^{\frac{1}{4}} \\
& \alpha l=\pi\left[\frac{25000 \times 0.0036 \times 6}{25000 \times 0.150 \times \sin 2 \times 31}\right]^{\frac{1}{4}} \\
& \alpha l=0.84 \mathrm{~m} \\
& \mathrm{~W}=\frac{1}{2} \times \sqrt{0.69 \times 0.69+0.84 \times 0.84} \\
& \mathrm{~W}=0.54 \mathrm{~m}
\end{aligned}
$$

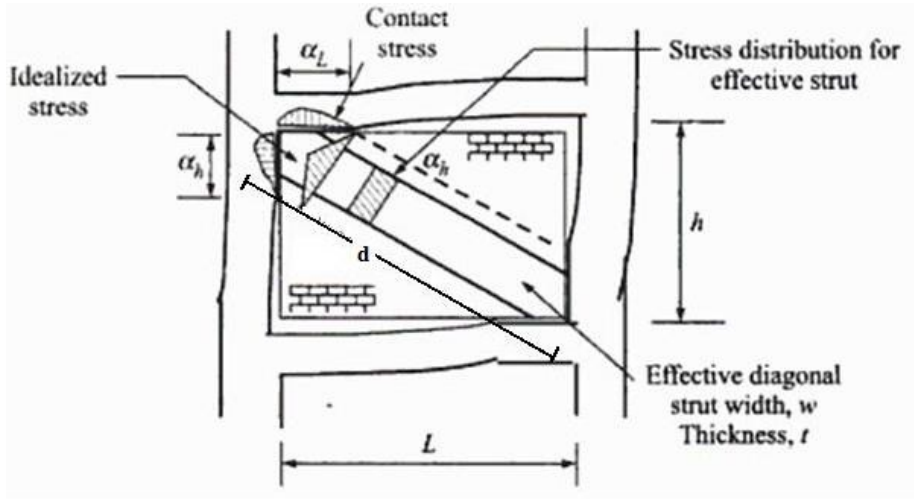

Fig. 5 Equivalent diagonal strut

\section{IDEALIZATION OF STRUCTURE}

To study the Seismic behavior of building structure while considering the effect of open ground storey, building frame is modeled as 3D space frame using standard two nodded frame element with two longitudinal degrees of freedom and one rotational degree of freedom at each node. At the interface of infill and frame, the infill element and the frame element are given same nodes.

The idealized form of a typical 5 bay x 2 bay 4 storey building frame with infill wall modeled as represented schematically in Fig. 6 the present study also considers 
bare frame to see how correctly the influence of open ground storey on Seismic behavior can be predicted.

A 5 bay x 2 bay building frames with 4 storey's on isolated footing have been considered. The height of each storey is taken as $3.1 \mathrm{~m}$. Thickness for roof and floor is taken as $120 \mathrm{~mm}$ and their corresponding dead load is directly applied on the beam. The brick infill with thickness $230 \mathrm{~mm}$. All the above dimensions were arrived on the basis of the design following the respective Indian code for design of reinforced concrete structure. However, these design data are believed to be practicable and hence, do not affect the generality of the conclusion.

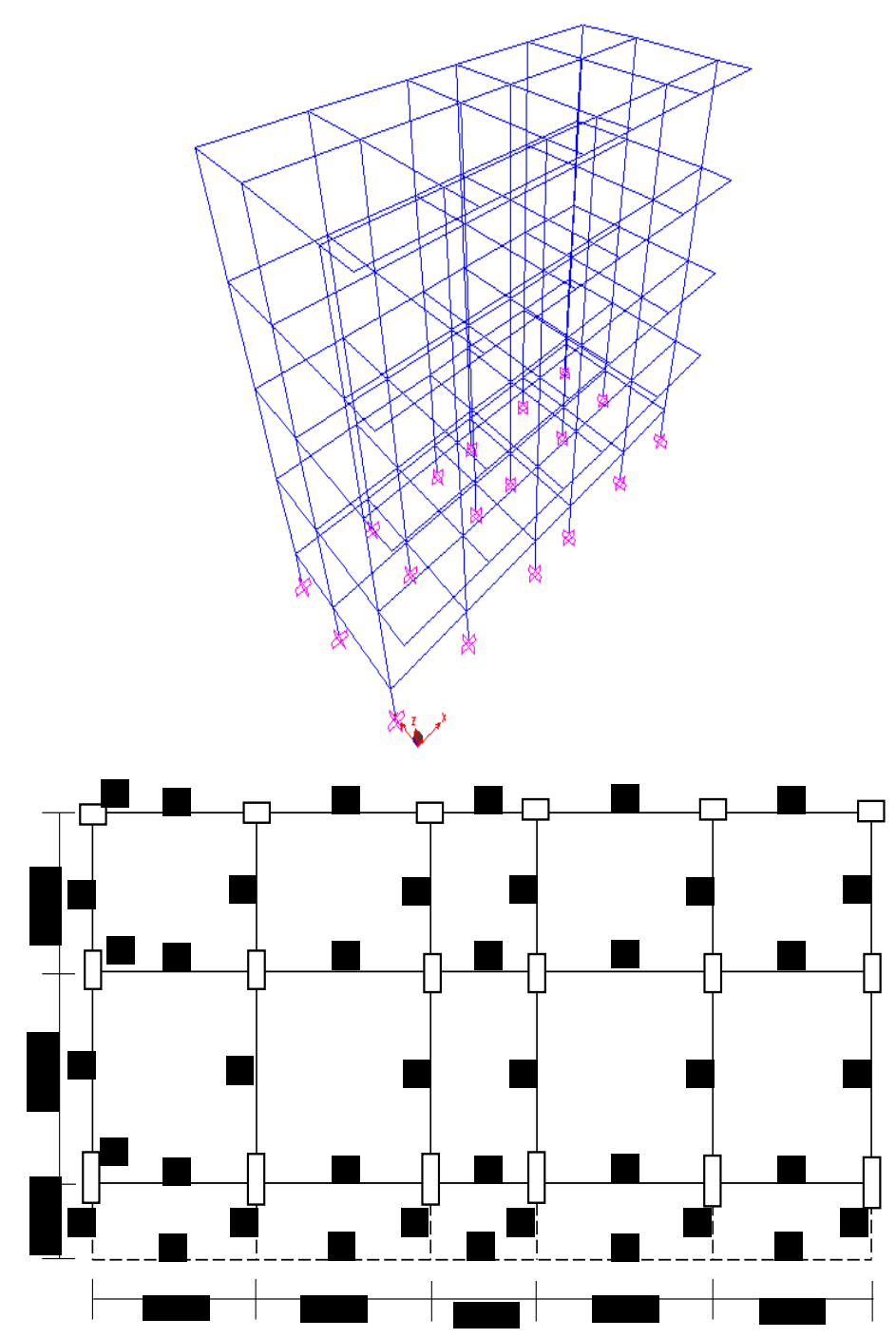

Fig. 6 Plan and Elevation of building 


\section{ANALYSIS OF TYPICAL BUILDING}

The plan layout and elevation of $\mathrm{G}+3$ storey building is shown in Fig. 6. The building considered is analyzed for all seismic zones.

\section{Data}

1) Live Load $=3 \mathrm{kN} / \mathrm{m}^{2}$ at typical floor

2) Earthquake load = As per IS-1893 (Part-1)-2002

3) Storey height $\quad=3.1 \mathrm{~m}$

4) Walls $=0.23 \mathrm{~m}$ thick

5) Slab thickness $\quad=0.12 \mathrm{~m}$

6) Density of concrete $=25 \mathrm{kN} / \mathrm{m}^{3}$

7) Density of brick $=20 \mathrm{kN} / \mathrm{m}^{3}$

Table 2. Section properties

\begin{tabular}{|c|c|c|c|}
\hline Columns & Size (mm) & Beams & Size (mm) \\
\hline $\mathrm{C} 1$ & $230 \times 450$ & $\mathrm{~B} 1$ & $230 \times 350$ \\
\hline $\mathrm{C} 2$ & $230 \times 400$ & $\mathrm{~B} 2$ & $230 \times 400$ \\
\hline $\mathrm{C} 3$ & $230 \times 350$ & $\mathrm{~B} 3$ & $230 \times 300$ \\
\hline & & $\mathrm{B} 4$ & $200 \times 400$ \\
\hline
\end{tabular}

Table 3. Properties of materials

\begin{tabular}{|c|c|c|}
\hline Materials & Modulus of elasticity $\left(\mathbf{k N} / \mathbf{m}^{2}\right)$ & Poisson's ratio \\
\hline Concrete M25 & $25 \times 10^{6}$ & 0.2 \\
\hline Masonry & $4.5 \times 10^{6}$ & 0.19 \\
\hline
\end{tabular}




\subsection{Variation of Different Zones}
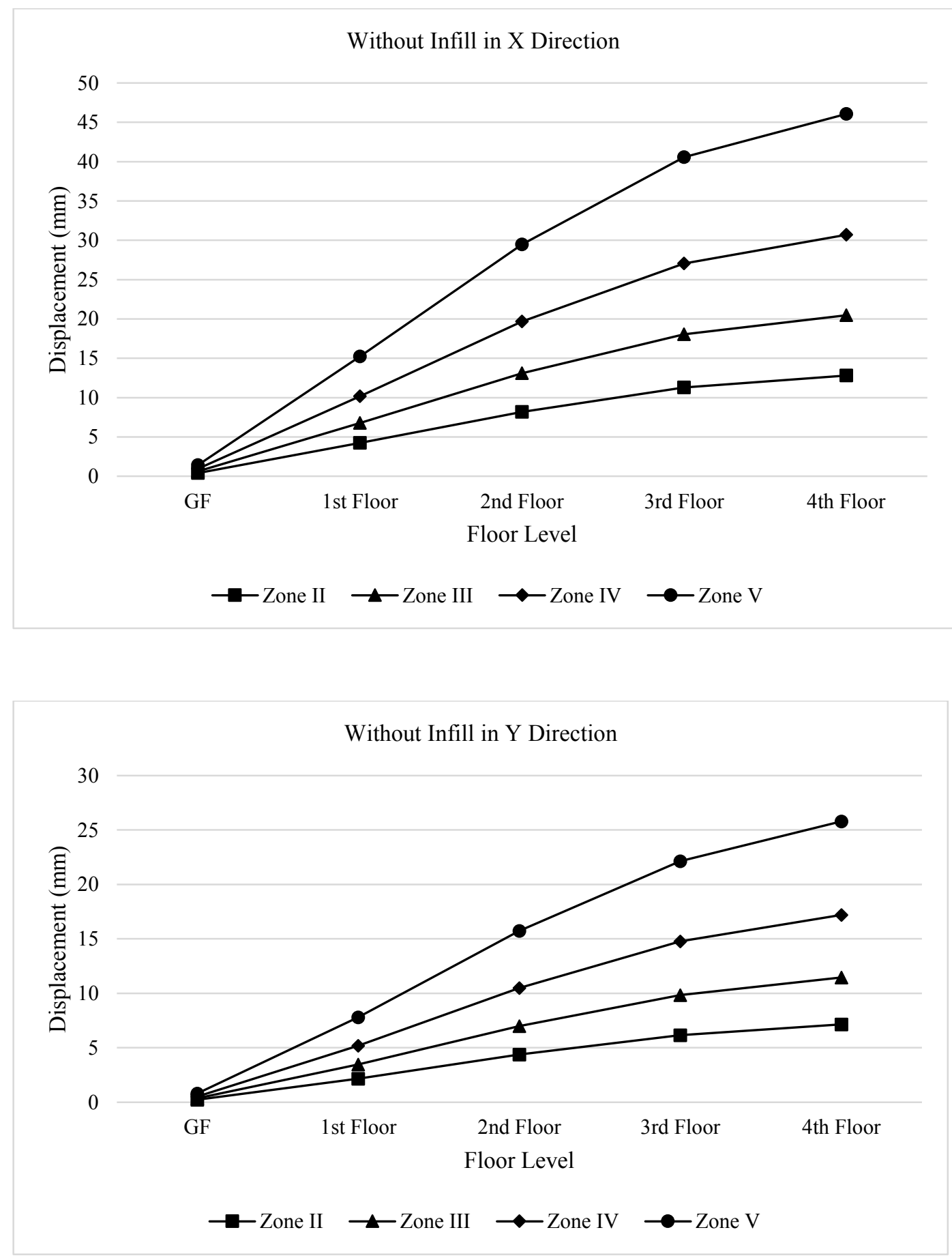

Fig. 7 Displacement variation for different zones in $\mathrm{X} \& \mathrm{Y}$ directions 


\subsection{Displacement comparison for open ground storey}

Table 4. Displacement comparison for open ground storey in $\mathrm{x}$ direction

\begin{tabular}{|c|c|c|c|c|}
\hline Zone & Floor Level & Without infill & Full infill & Open ground storey \\
\hline \multirow{4}{*}{ II } & GF & 0.393 & 0.007224 & 0.011 \\
\cline { 2 - 5 } & 1st Floor & 4.234 & 0.031 & 2.552 \\
\cline { 2 - 5 } & 2nd Floor & 8.191 & 0.059 & 2.587 \\
\cline { 2 - 5 } & 3rd Floor & 11.273 & 0.086 & 2.619 \\
\cline { 2 - 5 } & 4th Floor & 12.796 & 0.108 & 2.647 \\
\hline \multirow{4}{*}{ III } & GF & 0.629 & 0.012 & 0.017 \\
\cline { 2 - 5 } & 1st Floor & 6.774 & 0.05 & 4.083 \\
\cline { 2 - 5 } & 2nd Floor & 13.106 & 0.094 & 4.139 \\
\cline { 2 - 5 } & 3rd Floor & 18.038 & 0.138 & 4.19 \\
\cline { 2 - 5 } & 4th Floor & 20.474 & 0.173 & 4.235 \\
\hline \multirow{4}{*}{ IV } & GF & 0.943 & 0.017 & 0.026 \\
\cline { 2 - 5 } & 1st Floor & 10.162 & 0.075 & 6.124 \\
\cline { 2 - 5 } & 2nd Floor & 19.659 & 0.142 & 6.208 \\
\cline { 2 - 5 } & 3rd Floor & 27.056 & 0.207 & 6.285 \\
\cline { 2 - 5 } & 4th Floor & 30.711 & 0.259 & 6.352 \\
\hline \multirow{4}{*}{ V } & GF & 1.415 & 0.026 & 0.038 \\
\cline { 2 - 5 } & 1st Floor & 15.242 & 0.112 & 9.186 \\
\cline { 2 - 5 } & 2nd Floor & 29.488 & 0.212 & 9.312 \\
\hline & 3rd Floor & 40.585 & 0.31 & 9.428 \\
\hline & 4th Floor & 46.066 & 0.389 & 9.528 \\
\hline \multirow{4}{*}{} & & & & \\
\hline
\end{tabular}

Table 5. Displacement comparison for open ground storey in y direction

\begin{tabular}{|c|c|c|c|c|}
\hline Zone & Floor Level & Without infill & Full infill & Open ground storey \\
\hline \multirow{4}{*}{ II } & GF & 0.222 & 0.0089 & 0.012 \\
\cline { 2 - 5 } & 1st Floor & 2.165 & 0.053 & 1.022 \\
\cline { 2 - 5 } & 2nd Floor & 4.375 & 0.112 & 1.106 \\
\cline { 2 - 5 } & 3rd Floor & 6.153 & 0.178 & 1.192 \\
\cline { 2 - 5 } & 4th Floor & 7.164 & 0.242 & 1.278 \\
\hline \multirow{4}{*}{ III } & GF & 0.355 & 0.014 & 0.02 \\
\cline { 2 - 5 } & 1st Floor & 3.464 & 0.084 & 1.635 \\
\cline { 2 - 5 } & 2nd Floor & 7.001 & 0.179 & 1.769 \\
\hline
\end{tabular}




\begin{tabular}{|c|c|c|c|c|}
\hline \multirow{4}{*}{} & 3rd Floor & 9.845 & 0.285 & 1.908 \\
\cline { 2 - 5 } & 4th Floor & 11.462 & 0.388 & 2.045 \\
\hline \multirow{4}{*}{ IV } & GF & 0.532 & 0.021 & 0.03 \\
\cline { 2 - 5 } & 1st Floor & 5.196 & 0.126 & 2.453 \\
\cline { 2 - 5 } & 2nd Floor & 10.501 & 0.269 & 2.654 \\
\cline { 2 - 5 } & 3rd Floor & 14.768 & 0.427 & 2.862 \\
\cline { 2 - 5 } & 4th Floor & 17.193 & 0.582 & 3.068 \\
\hline \multirow{4}{*}{ V } & GF & 0.799 & 0.032 & 0.045 \\
\cline { 2 - 5 } & 1st Floor & 7.795 & 0.19 & 3.679 \\
\cline { 2 - 5 } & 2nd Floor & 15.752 & 0.403 & 3.981 \\
\cline { 2 - 5 } & 3rd Floor & 22.152 & 0.641 & 4.293 \\
\cline { 2 - 5 } & 4th Floor & 25.79 & 0.872 & 4.602 \\
\hline
\end{tabular}

\section{CONCLUSIONS}

Followings are the salient conclusions obtained from the present study

1. Stiffness of the structure is an important factor in case of OGS type building, in the present study infill can improve stiffness of structure but in to some extent, that is not enough to save structure against seismic effect.

2. Problem of OGS buildings cannot be identified properly through elastic analysis as the stiffness of OGS building and Bare-frame building are almost same.

RC frame building with open first storeys are known to perform poorly during in strong earthquake shaking. In this study, the vulnerability of building with soft storey is shown an example building.

\section{REFERENCES}

[1]. A. F. C. Dya and A. W. C. Oretaa, "Seismic vulnerability assessment of soft story irregular buildings using pushover analysis," Procedia Engineering, vol. 125, pp. 925 - 932, 2015.

[2]. A. Wibowo, J. L. Wilson, N. TK Lam and E. F Gad, "Collapse behaviour assessment of precast soft storey building," Procedia Engineering, vol. 125, pp. $1036-1042,2015$.

[3]. E. Jennings, J. W. Lindt, E. Ziaei, G. Mochizuki, W. Pang and X. Shao, "Retrofit of a soft-story woodframe building using SMA devices with full-scale hybrid test verification," Engineering Structures, vol. 80, pp. 469-485, 2014. 
[4]. D. R. Sahoo and D. C. Rai, "Design and evaluation of seismic strengthening techniques for reinforced concrete frames with soft ground story," Engineering Structures, vol. 56, pp. 1933-1944, 2013.

[5]. N. Kirac, M. Dogan and H. Ozbasaran, "Failure of weak-storey during earthquakes," Engineering Failure Analysis, vol. 18, pp. 572-581, 2011.

[6]. F. Hejazi, S. Jilani, J. Noorzaei, C. Y. Chieng, M. S. Jaafar and A. A. Abang Ali, "Effect of Soft Story on Structural Response of High Rise Buildings," Materials Science and Engineering, vol. 17, pp. 1-13, 2011.

[7]. P. Sarkar, A. M. Prasad, D. Menon, "Vertical geometric irregularity in stepped building frames," Engineering Structures, vol. 32, pp. 2175 - 2182, 2010.

[8]. A. Wibowo, J. L. Wilson, N. TK Lam and E. F Gad, "Collapse modelling analysis of a precast soft storey building in Australia," Engineering Structures, vol. 32, pp. 1925 - 1936. 2010.

[9]. C.J. Athanassiadou, (2008). "Seismic performance of $\mathrm{R} / \mathrm{C}$ plane frames irregular in elevation”, Engineering Structures, vol. 30, pp. 1250-1261, 2008.

[10]. H. S. Lee and D.W. Ko "Seismic response characteristics of high-rise RC wall buildings having different irregularities in lower stories," Engineering Structures, vol. 29, pp. 3149-3167, 2007.

[11]. M. Yoshimura, "Nonlinear Analysis of a Reinforced Concrete Building with a Soft First Story Collapsed by the 1995 Hyogoken-Nanbu Earthquake," Cement and Concrete Composites, vol. 19, pp. 213-221, 1997. 
